\begin{tabular}{|l|l|l|}
\hline \multicolumn{2}{|c|}{ PublisherInfo } \\
\hline \hline PublisherName & $:$ & BioMed Central \\
\hline \hline PublisherLocation & $:$ & London \\
\hline \hline PublisherImprintName & $:$ & BioMed Central \\
\hline \hline
\end{tabular}

\title{
Viral protein K5 modulates T-cell costimulation
}

\begin{tabular}{|l|l|l||}
\hline \multicolumn{2}{|c|}{ ArticleInfo } \\
\hline \hline ArticleID & $:$ & 4123 \\
\hline \hline ArticleDOI & $:$ & $10.1186 /$ gb-spotlight-20010620-01 \\
\hline \hline ArticleCitationID & $:$ & spotlight-20010620-01 \\
\hline \hline ArticleSequenceNumber & $:$ & 194 \\
\hline \hline ArticleCategory & $:$ & Research news \\
\hline ArticleFirstPage & $:$ & 1 \\
\hline \hline ArticleLastPage & $:$ & 2 \\
\hline \hline & $:$ & RegistrationDate : 2001-06-20 \\
ArticleHistory & $:$ & OnlineDate \\
\hline \hline ArticleCopyright & $:$ & BioMed Central Ltd2001-06-20 \\
\hline \hline ArticleGrants & $:$ & \\
\hline \hline ArticleContext & $:$ & 130592211 \\
\hline \hline
\end{tabular}




\section{Tudor Toma}

Email: ttoma@mail.dntis.ro

Herpesviruses use elaborate strategies to establish themselves in their host, including evading, destroying or redirecting immune cells. In the June 15 Journal of Clinical Investigation, Coscoy and Ganem describe how viral proteins from the human herpesvirus associated with Kaposi's sarcoma impair the ability of $\mathrm{B}$ cells to induce the protective response of cytotoxic $\mathrm{T}$ lymphocytes.

Coscoy and Ganem examined the ability of two viral genes, $K 3$ and $K 5$, to influence the disposition of host surface proteins implicated in immune recognition and activation. They found that expression of $\mathrm{K} 5$, but not K3, in B cells dramatically reduces the expression of ICAM-1 and B7-2 on the cell surface, causing these proteins to be internalized rapidly and routed to the lysosome. This downregulation of two proteins known to be important in signalling between cells of the immune system is functionally significant, because $\mathrm{K} 5$-transfected B cells show substantial impairment in their ability to induce T-cell activation ( $J$ Clin Invest 2001, 107:1599-1606).

K5 is thus the first example of a viral modulator of immunological synapse formation and T cell costimulation, and its effect is probably most important early in the disease when most viral antigens are confined to infected B cells.

\section{References}

1. Coscoy L, Ganem D: A viral protein that selectively downregulates ICAM-1 and B7-2, key components of the immunological synapse, modulates T cell costimulation. J Clin Invest 2001, 107:1599-1606., [http://www.jci.org/cgi/content/abstract/107/12/1599]

This PDF file was created after publication. 